Article

\title{
Graphene Nanosheets to Improve Physico-Mechanical Properties of Bioactive Calcium Silicate Cements
}

\author{
Nileshkumar Dubey ${ }^{1}$, Sneha Sundar Rajan ${ }^{1}$, Yuri Dal Bello ${ }^{2}$, Kyung-San Min ${ }^{3}$ and \\ Vinicius Rosa 1,4,* \\ 1 Faculty of Dentistry, National University of Singapore, Singapore 119083, Singapore; \\ a0121941@u.nus.edu (N.D.); sneha.xanotor@gmail.com (S.S.R.) \\ 2 Faculty of Dentistry, University of Passo Fundo, Passo Fundo 99052-900, Brazil; yuri@upf.br \\ 3 School of Dentistry and Institute of Oral Bioscience, Chonbuk National University, Jeonju-si 54896, Korea; \\ endomin@gmail.com \\ 4 Centre for Advanced 2D Materials and Graphene Research Centre, National University of Singapore, \\ Singapore 117546, Singapore \\ * Correspondence: denvr@nus.edu.sg; Tel.: +65-6779-5555
}

Academic Editor: Barbara Zavan

Received: 8 May 2017; Accepted: 22 May 2017; Published: 31 May 2017

\begin{abstract}
Bioactive calcium silicate cements are widely used to induce mineralization, to cement prosthetic parts, in the management of tooth perforations, and other areas. Nonetheless, they can present clinical disadvantages, such as long setting time and modest physico-mechanical properties. The objective of this work was to evaluate the potential of graphene nanosheets (GNS) to improve two bioactive cements. GNS were obtained via reduction of graphite oxide. GNS were mixed $(1,3,5$, and $7 \mathrm{wt} \%$ ) with Biodentine (BIO) and Endocem $\mathrm{Zr}$ (ECZ), and the effects on setting time, hardness, push-out strength, $\mathrm{pH}$ profile, cell proliferation, and mineralization were evaluated. Statistics were performed with two-way ANOVA and Tukey test $(\alpha=0.05)$. GNS has not interfered in the composition of the set cements as confirmed by Raman, FT-IR and XRD. GNS (1 and $3 \mathrm{wt} \%$ ) shortened the setting time, increased hardness of both materials but decreased significantly the push-out strength of ECZ. $\mathrm{pH}$ was not affected but $1 \mathrm{wt} \%$ and $7 \mathrm{wt} \%$ to $\mathrm{ECZ}$ and $5 \mathrm{wt} \%$ to BIO increased the mineralization compared to the controls. In summary, GNS may be an alternative to improve the physico-mechanical properties and bioactivity of cements. Nonetheless, the use of GNS may not be advised for all materials when effective bonding is a concern.
\end{abstract}

Keywords: graphene; Biodentine; dental pulp stem cells; push-out bond strength; mineral trioxide aggregate

\section{Introduction}

Bioactive cements are widely used for the management of perforations, retrograde root filling, pulp capping, cementation of prosthetic parts, and others [1-3]. Biodentine (BIO) and Endocem-Zr (ECZ) are different from the usual bioactive calcium-silicate "Portland cement" materials as it contains zirconia oxide instead of bismuth oxide as the radiopacifying agent. It is the safest bioactive cements that exhibits the least discoloration and calcification of the tooth and pulp chamber, respectively $[4,5]$. These bioactive cements can induce higher expression of several genes (e.g., bone sialoprotein, dentin sialophosphoprotein, alkaline phosphatase, osteocalcin) and phosphatase activity, hence, stimulating biomineralization [6-9]. Nonetheless, these cements may present some clinical disadvantages, such as long setting time and modest physico-mechanical properties $[9,10]$. Thus, the development of materials and strategies that can improve these aspects without compromising the bioactivity of cements is of high interest. 
The addition of nanomaterials into biocements can improve their physical and chemical properties. For example, nanosilica promotes early precipitation and shortens the induction period of Portland cement (42.5 grade) decreasing the setting time and increasing the compressive strength [11]. The addition of $15 \mathrm{vol} \%$ of zirconia and $30 \mathrm{vol} \%$ of alumina to hydroxyapatite increased the flexural strength and fracture toughness by almost three times compared to pure hydroxyapatite [12]. Similar improvement can be observed with the addition of single-walled carbon nanotubes (CNTs) which accelerates the hydration of cements at an early age [13]. Furthermore, the addition of multi-walled CNTs can improve both the compressive strength and modulus of rupture of cementitious materials [14-16].

Graphene is a novel nanomaterial that has large surface area, high elastic modulus, flexural strength, and others [17]. Pristine graphene films can increase osteogenic differentiation of stem cells [18], while graphene oxide (GO) has been recently shown to increase the expression of osteogenic and odontogenic-related genes when used as a substrate to culture dental pulp stem cells (DPSCs) [19]. Additionally, these materials have been previously shown to improve physical and mechanical properties of cementitious products. For example, GO can increase the compressive strength of ordinary Portland cement by $33 \%$ and the flexural strength by 59\% [20]. Similarly, the addition of GO to Portland cement paste can increase the compressive and tensile strength by $46 \%$ and $53 \%$, respectively [21]. In fact, the improvements in mechanical properties of Portland cements by GO is concentration-dependent. The addition of GO can increase both the compressive and flexural strengths by $72 \%$ and $63 \%$ after seven days from mixing [22]. The presence of $1 \mathrm{wt} \%$ graphene nanosheets (GNS) in HAp-based composites have shown to improve the Vickers hardness by $30 \%$ compared to pure hydroxyapatite [23]. Also, the incorporation of $1 \mathrm{wt} \%$ GNS in calcium silicate ceramic composite have increase the fracture toughness by $130 \%$ [24]. Furthermore, $1 \mathrm{wt} \%$ GNS addition in bioceramics have promoted cell viability and cell proliferation and improved apatite mineralization compared to bioceramic alone $[23,24]$. Despite the improvements provided by different forms of graphene in cementitious materials, the potential of graphene-based materials to improve properties of bioactive cements remains largely unknown.

The objective of this work was to evaluate the effects of graphene nanosheets on the bioactivity, physicomechanical and chemical properties of two bioactive cements. The hypothesis tested was that GNS can increase all the properties studied in a dose-dependent manner without compromising the materials' bioactivity.

\section{Results}

GNS with several micrometers in lateral size was successfully produced through the chemical reduction of GO using hydrazine vapor (Figure 1A). Raman spectroscopy (Figure 1B) showed two high intensity peaks at 1583 and $2700 \mathrm{~cm}^{-1}$ explicitly for $\mathrm{G}$ and $2 \mathrm{D}$ bands. The $\mathrm{G}$ band depicts the stretching of the $\mathrm{C}-\mathrm{C}$ bond in graphitic materials and $2 \mathrm{D}$ band is common to all $\mathrm{sp}^{2}$ carbon systems and is used to determine the number of graphene layers. The peak observed at $1060 \mathrm{~cm}^{-1}$ in the Fourier transform infrared spectroscopy (FT-IR) spectrum (Figure 1C) indicates structural vibrations from unoxidized graphitic domain and remaining carbonyl groups after the reduction process. The $\mathrm{C}=\mathrm{O}$ at $1720 \mathrm{~cm}^{-1}$ is due to the peeling of graphitic structures through the insertion of oxygen between the graphene sheets during oxidation process [25]. The spectra show a peak at $3400 \mathrm{~cm}^{-1}$ corresponding to the stretching and bending vibration of $\mathrm{O}-\mathrm{H}$ groups of water molecules adsorbed on graphene oxide. All of the characteristic absorption bands of oxygen-containing groups $(\mathrm{O}-\mathrm{H}, \mathrm{C}=\mathrm{O}$, and $\mathrm{C}-\mathrm{O})$ are substantially weakened and almost eliminated (Figure 1C). This confirms the reduction of graphene oxide to graphene nanosheets. 

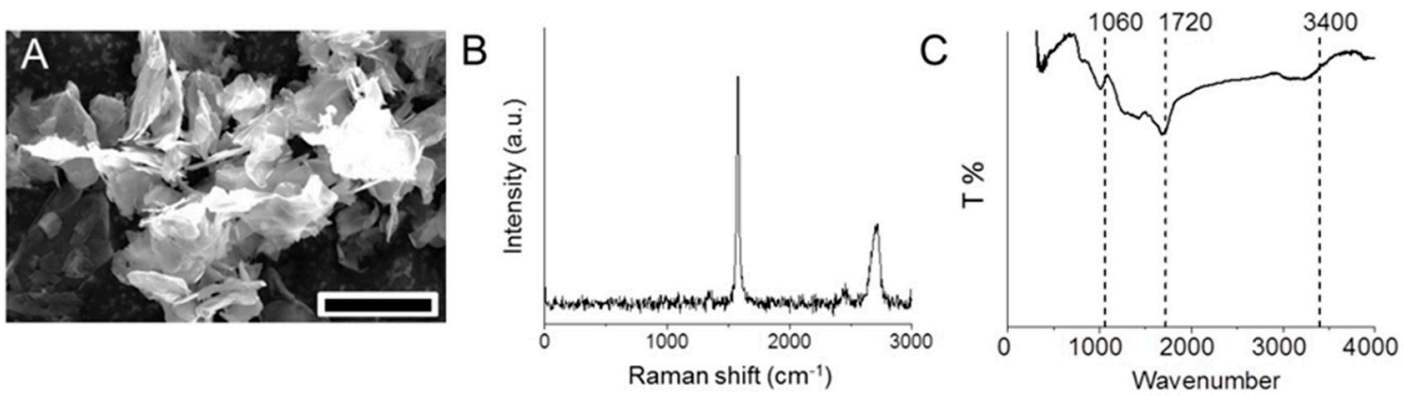

Figure 1. GNS characterization via SEM (A), scale bar = $10 \mu \mathrm{m}$; Raman (B); and FT-IR (C) spectroscopy.

The microstructures of both biocements with different proportions of GNS are shown in Figure 2. Both biocements showed the presence of peaks at $\sim 830$ and $850 \mathrm{~cm}^{-1}$ corresponding to tri- and di-calcium silicate. The mixing procedures and setting reaction did not change GNS structure as the Raman spectroscopy confirmed the presence of peaks at 1583 and $2700 \mathrm{~cm}^{-1}$ for all the experimental groups (Figure 3). It is possible to observe that GNS kept its sheet-like shape and was evenly dispersed within the cements matrices after mixing (Figure 2).
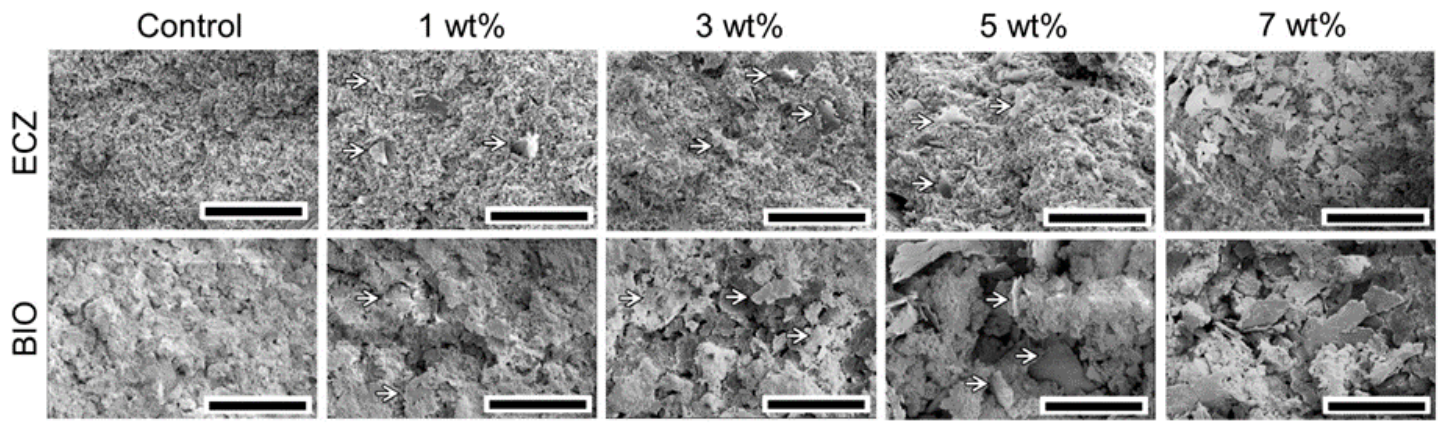

Figure 2. SEM of fracture surface of specimens showed that GNS (arrows) was evenly dispersed in the cements (scale bar $=50 \mu \mathrm{m})$.

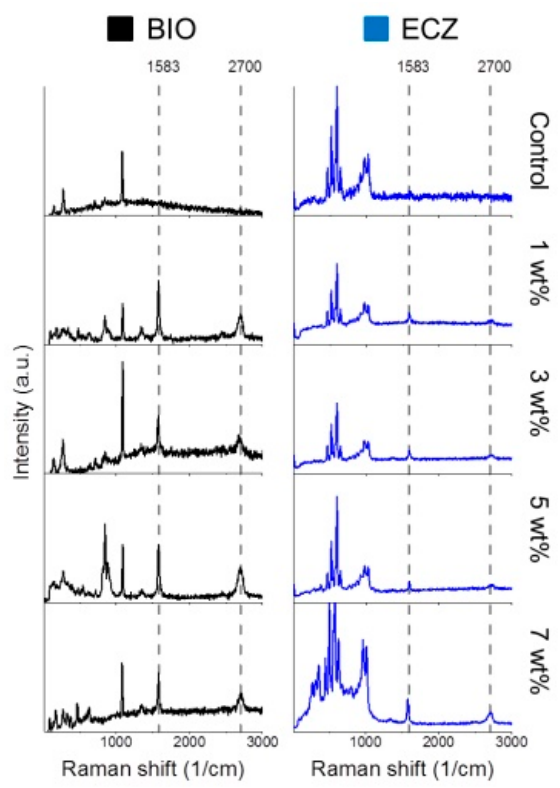

Figure 3. Raman spectroscopy shows the presence of peaks at 1583 and $2700 \mathrm{~cm}^{-1}$ for all of the experimental groups. 
The crystalline phases of BIO and ECZ with different GNS contents were investigated by X-ray powder diffraction (XRD) (Figure $4 \mathrm{~A}$ ). Both materials exhibited peaks for calcium carbonate $\left(\mathrm{CaCO}_{3}\right)$ at $29.35^{\circ}$. Zirconium oxide $\left(\mathrm{ZrO}_{2}\right)$ peaks were observed at $8.17^{\circ}$ and $31.47^{\circ}$ in both materials but more intensively in ECZ. The $\mathrm{ZrO}_{2}$ acts as a radio pacifier in substitution for bismuth oxide present in mineral trioxide aggregate (MTA) [26]. Though the intensities of the peaks varied with the addition of GNS, there was no extinction or shift of any peak compared to the unmodified materials (Control) suggesting that the hydration was not negatively affected by the presence of GNS.

The FTIR analysis was performed to determine the spectral changes between both BIO and ECZ with the incorporated GNS (Figure 4B). The cements showed the presence of calcium hydroxide $\left(\mathrm{Ca}(\mathrm{OH})_{2}\right)$ with peaks between at $3640 \mathrm{~cm}^{-1}$. Furthermore, BIO and ECZ showed the presence of calcium carbonate peaks around $700-850 \mathrm{~cm}^{-1}$ and $1400-1480 \mathrm{~cm}^{-1}$ occurring because of the stretching and bending of $-\mathrm{CO}_{3}{ }^{2-}$ [27]. The presence of tricalcium silicate was observed in BIO with a peak around $850-874 \mathrm{~cm}^{-1}$ occurring due to stretching of $-\mathrm{SiO}_{4}{ }^{4-}$. Additional $-\mathrm{OH}$ group is also seen around $1640 \mathrm{~cm}^{-1}$ in both materials depicting the $\mathrm{H}-\mathrm{O}-\mathrm{H}$ bending vibrations of $\mathrm{H}_{2} \mathrm{O}$ molecules [28]. Moreover, the characteristic peaks of GNS was recognized as the symmetric stretching of $\mathrm{CH} 2$ at $2850 \mathrm{~cm}^{-1}$ and asymmetric stretching of CH2 at $2920 \mathrm{~cm}^{-1}$ at the edges/defects.

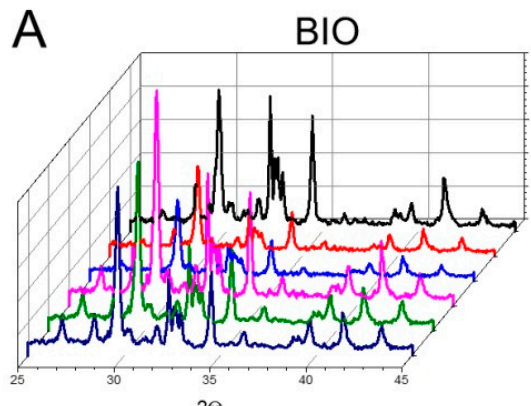

$2 \Theta$

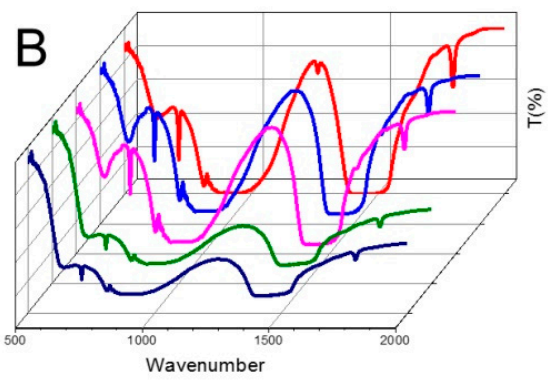

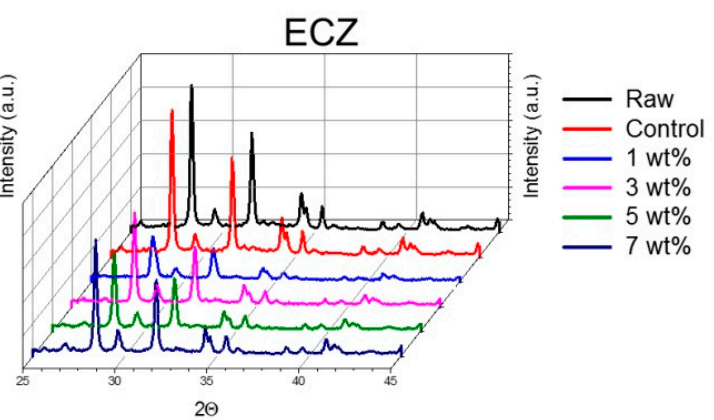

$2 \Theta$

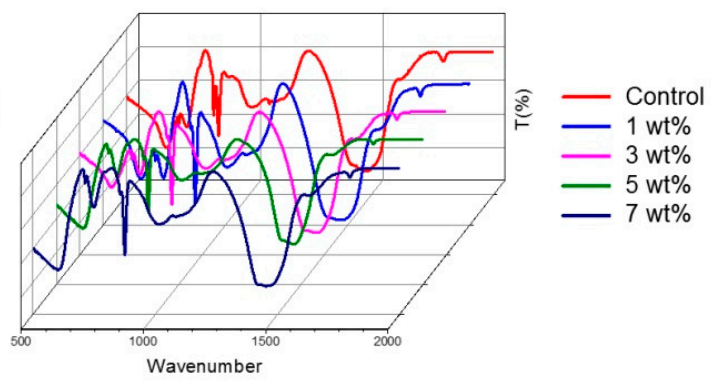

Figure 4. XRD (A) and FT-IR (B) for all conditions tested (Raw = unmodified powder before mixing).

Setting time, hardness, and push-out bond strength are shown in Figure 5. BIO presented longer setting time (A), higher hardness (B), and push-out bond strength (C) comparing to ECZ for all the conditions tested $(p<0.05)$. The addition of GNS to ECZ resulted in significant decrease of push-out bond strength for all the weight percentages tested $(C)$. The fracture patterns obtained from the push-out test are presented in the Figure S1.

The $\mathrm{pH}$ variation of both materials with different weight percentages of GNS is shown in Figure 6. The addition of GNS did not change the alkaline potential of the materials tested (* represents statistical significance between groups, $p<0.05$ ). Fluorescence micrographs (Figure 7A) showed that DPSCs were successfully attached and did not exhibit any obvious effects on cell proliferation when treated with GNS-bioactive cement extract. Bioactivity was assessed by Alizarin red S staining. There was no statistical difference for the absorbance values observed for BIO and ECZ for the same condition except for $1 \mathrm{wt} \%$ of GNS (Figure 7B). The full set of data for cell viability is available in Figure S2. 


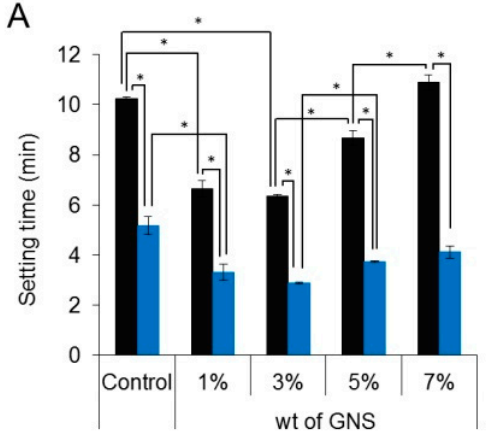

BIO $\square$ ECZ
B

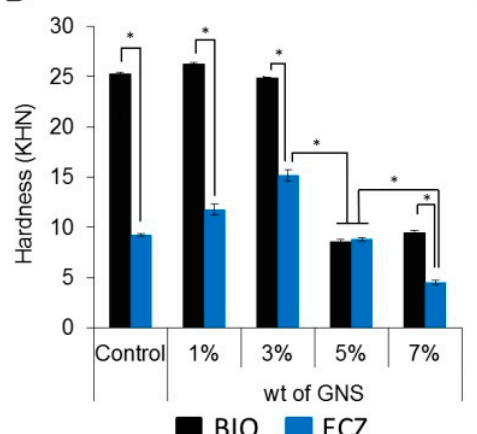

C

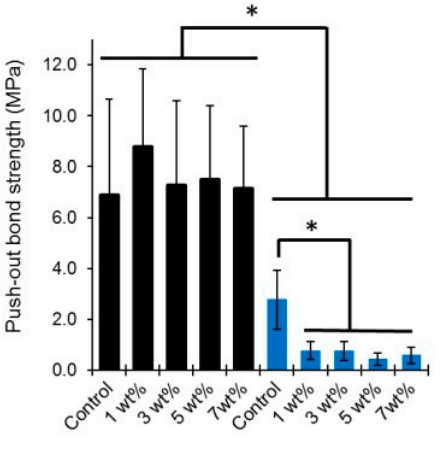

BIO $\square$ ECZ

Figure 5. Setting time (A); hardness (B); and push-out bond strength $(\mathbf{C})$ of the groups tested ( ${ }^{*}$ represents statistical significance between groups, $\left.p<0.05\right)$. The fracture modes obtained in the push-out test are available in Figure S1.
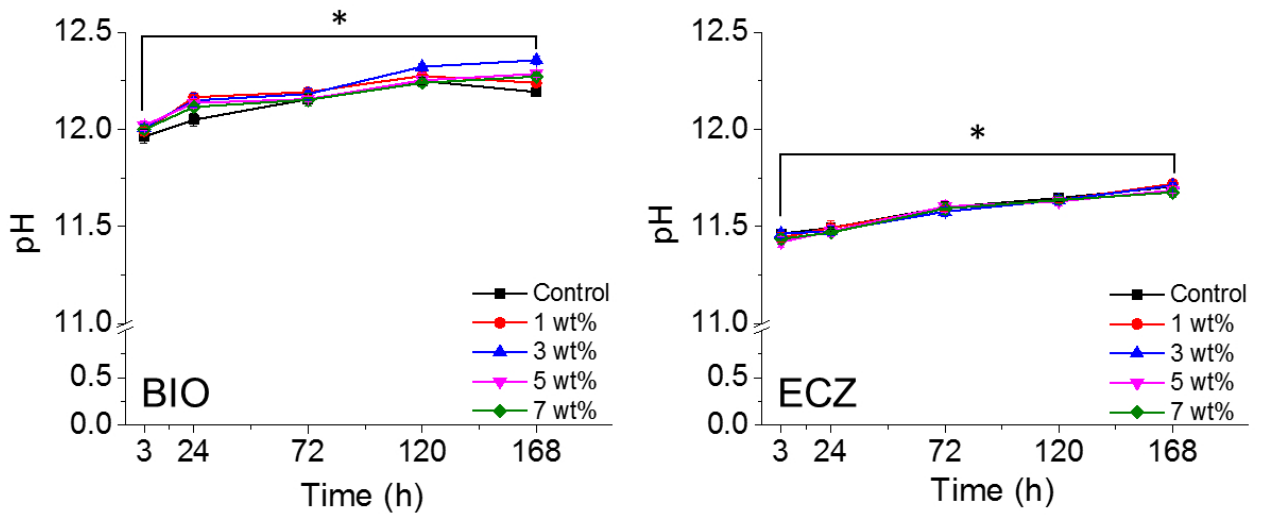

Figure 6. $\mathrm{pH}$ variation of both materials with different wt $\%$ of GNS. The addition of GNS did not change the alkaline potential of the materials tested (* represents statistical significance between groups, $p<0.05)$.
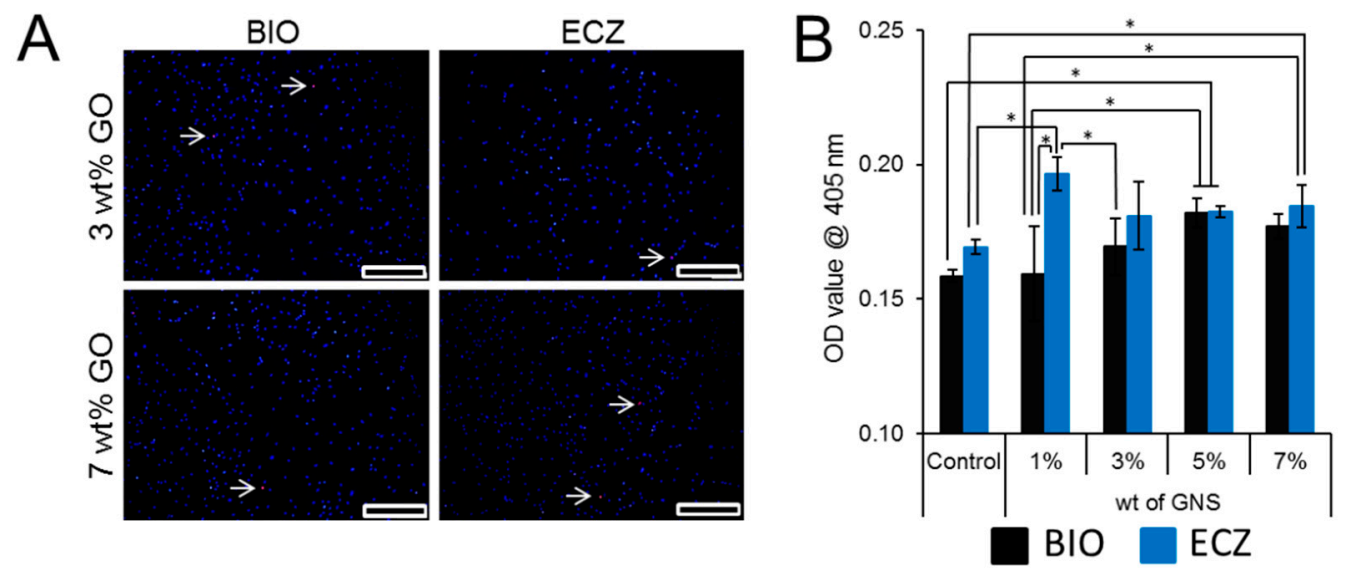

Figure 7. Cell viability was not compromised by the addition of 3 and $7 \mathrm{wt} \%$ of GNS after five days. The arrow indicates the dead cell in culture (A); bioactivity was assessed by Alizarin red S staining. There was no statistical difference for BIO and ECZ for the same condition except for $1 \mathrm{wt} \%$ of GNS (B). Scale bar $=20 \mu \mathrm{m}$, the full set of data for three and five days for cell viability is available in Figure S2. 


\section{Discussion}

Bioactive cements have been used as a root end filling material and prospective studies have reported a failure of $9.8-16 \%$ at one year $[29,30]$. The incorporation of graphene-based material has been proposed for many materials, such as Portland cements and bioceramics, to improve mechanical properties and reduce setting time $[20,21,23,24]$. In this regard, the addition of GNS to bioactive cements should improve the physico-mechanical properties, proliferation, and mineralization potential to extend their clinical use.

The addition of GNS did not change the composition of crystalline phases of both bioactive cements tested (Figure 4B). A similar trend has been observed for Portland cements where the addition of GO did not result in difference in the positions of the XRD peaks [22]. The FTIR analysis (Figure 4B) showed that the spectrum of the mixed cement reinforced with different proportions of GNS exhibit bands comparable with those of the unmodified cements (Control). These confirm that the GNS do not chemically react with the cements during their setting reaction.

Regardless the addition of GNS, ECZ presented significant shorter setting time and lower hardness as compared to $\mathrm{BIO}$ (Figure $5 \mathrm{~A}, \mathrm{~B}$ ). The faster setting reaction of $\mathrm{ECZ}$ can be attributed to the presence of small particles of pozzolan cement which increases the surface contact of the particles with the mixing liquid and provides rapid setting and ease of handling [31]. It is noteworthy that BIO also presented relatively short setting time compared to other MTA-based materials that can take twice as much time to complete the setting reaction [9,31]. This can be partially explained by the presence of calcium carbonate in $\mathrm{BIO}$ which acts as a nucleation site for calcium silicate hydrate (C-S-H), thereby reducing the duration of the induction period [32]. The addition of $3 \mathrm{wt} \%$ of GNS to the mix resulted in significantly lower setting time for both materials compared to the control. It is feasible that carbon-based materials influence both the initial $C_{3} A$ and the $C_{3} S$ hydration products by accelerating the rate of hydration processes particularly at early stages since they act as a matrix for the development of C-S-H and calcium hydroxide [22,33,34]. The longer setting time observed for 5 and $7 \mathrm{wt} \%$ compared to $3 \mathrm{wt} \%$ may be related to the fact that, at high concentrations, carbon-based materials can agglomerate around cement grains allowing only partial hydration [35]. In this case, the hydrated product can present weak bonds which correlates to lower hardness values observed for 5 and $7 \mathrm{wt} \%$ (Figure 5B). The lower hardness observed for ECZ can also be related to the presence of $\mathrm{ZrO}_{2}$ (Figure 4A). It has been shown that when zirconia is used as a reinforcing agent in concentrations as high as $8 \mathrm{wt} \%$, it can disrupt the hydroxyapatite microstructure reducing significantly the hardness of hydroxyapatite-based nanocomposites [36].

The effective bond of materials to dentin is crucial for the success of endodontic procedures. In general, BIO presented higher push-out bond strength as compared to ECZ regardless of the presence of GNS (Figure 5C). The presence of GNS decreased significantly the push-out strength of ECZ. Once there is no chemical reaction between GNS and ECZ (Figure 4A,B) it is possible that the GNS act as impurities within the cementitious matrix or prevent effective contact between ECZ and dentin resulting in lower push-out strength. High push-out bond strength has been previously reported for BIO compared to other root perforation repair materials such as Intermediate Restorative Material (IRM), MTA and others [37,38]. Interestingly, the GNS did not compromise the push-out strength for BIO. This can be related to the small particle size and uniform components of BIO that promote a good interlocking of material with dentine microstructure [38]. In addition, it may be related to the possible higher dissolution of $\mathrm{Ca}$ and $\mathrm{Si}$ ions in BIO that are exchanged with dentin resulting in the formation of tag-like structures in the material/dentin interface [39].

There was a significant increase in the $\mathrm{pH}$ of both biocements from 3 to $168 \mathrm{~h}$ for all of the conditions tested (Figure 6). In addition, BIO presented consistently higher $\mathrm{pH}$ for all the conditions and time points tested compared to ECZ. The increase of $\mathrm{pH}$ is related to the hydration of tricalcium silicate that results in the formation of calcium silicate hydrate gel and calcium hydroxide. The latter provides an alkaline $\mathrm{pH}$ in the surroundings upon $\mathrm{Ca}^{2+}$ dissolution $[9,40]$. The addition of GNS does 
not change the alkaline profile of the materials tested. This is of high importance for clinicians as the high $\mathrm{pH}$ can be associated with the antibacterial potential of these cements [41].

The effects of GNS in dental pulp stem cells proliferation was assessed using an indirect-direct method where the materials are soaked in basal culture medium and the extracts used to treat cells for a given period of time [42]. The addition of GNS did not increase the cytotoxicity of both materials after five days as few cells are stained with propidium iodide (white arrows in Figure 7A). Both BIO and ECZ can promote mineralization in DPSC as the absorbance obtained were statistically higher than the one obtained with basal medium $(0.07 \pm 0.01)$ although lower than with the use of osteogenic medium $(0.40 \pm 0.01)$. Although BIO presented higher $\mathrm{pH}$ than ECZ (Figure 6), the first failed to induce higher degrees of mineralization (Figure 7B). Although alkalinity plays an important in the mineral production, the differentiation of stem cells towards mineral-producing phenotype is also affected by the amount of calcium ions present in the microenvironment [9]. Surprisingly the addition of 1 and $7 \mathrm{wt} \%$ of GNS in ECZ was capable of increasing the mineralization of DPSC as compared to the control. For BIO, only the addition of $5 \mathrm{wt} \%$ was capable of exerting the similar response. Further studies are necessary to evaluate if these concentrations can increase calcium dissociation from these biocements.

\section{Materials and Methods}

\subsection{Sample Preparation}

Multilayer graphene nanosheets (GNS) were synthesized by the reduction of GO as previously described [43]. GO was prepared via the modified Hummer's method [19]. Briefly, $5 \mathrm{~g}$ of graphite (Lanka Graphite Ltd., Melbourne, Australia) were mixed with $2.5 \mathrm{~g}$ of $\mathrm{NaNO}_{3}$ in a solution of $12 \mathrm{~mL}$ $\mathrm{H}_{3} \mathrm{PO}_{4}$ and $108 \mathrm{~mL} \mathrm{H}_{2} \mathrm{SO}_{4}$ in ice bath for $10 \mathrm{~min}$. Following, $15 \mathrm{~g}$ of $\mathrm{KMnO}_{4}$ was gradually added and the suspension was stirred on ice bath for $2 \mathrm{~h}$ followed by additional $60 \mathrm{~min}$ at $40{ }^{\circ} \mathrm{C}$. Subsequently, the temperature of the mixture was increased to $98^{\circ} \mathrm{C}$ and kept for $60 \mathrm{~min}$ while deionized water was added to a final volume of $400 \mathrm{~mL}$. After $5 \mathrm{~min}, 15 \mathrm{~mL}$ of $\mathrm{H}_{2} \mathrm{O}_{2}$ was added and the reaction product was centrifuged and washed with $5 \% \mathrm{HCl}$ solution in deionized water. Finally, $0.1 \mathrm{~g}$ of graphite oxide was dispersed in $100 \mathrm{~mL}$ of deionized water via ultrasonication and hydrazine was added to promote the reduction of GNS at $80{ }^{\circ} \mathrm{C}$. After, two bioactive cements namely BIO (Biodentine, Septodont, Saint-Maur-des-Fossés, France) and ECZ (EndocemZr, Maruchi, Gangwon-do, Korea) were combined with different proportions of GNS in powder form (1, 3, 5 and $7 \mathrm{wt} \%)$. BIO and ECZ without GNS were used as controls. For all assays, the powders were mixed per manufacturer instructions and transferred to molds. All of the mixtures were allowed to set for $24 \mathrm{~h}\left(37^{\circ} \mathrm{C}, 95 \%\right.$ humidity) prior testing (except for setting time, $\mathrm{pH}$ and push-out testing).

Sample characterization: Raman spectroscopy, Fourier transform infrared spectroscopy (FTIR), scanning electron microscopy (SEM), and X-ray diffraction (XRD)

Raman spectra were obtained using a CRM 200 (Witec, Ulm, Germany) connected to a microscope with $100 \times$ magnification. The spectra were obtained with an excitation laser source of $532 \mathrm{~nm}$ laser with a power of $0.1 \mathrm{~mW}$ for $10 \mathrm{~s}$.

For SEM, disks were fractured and the cross-sections observed under SEM (Quanta 650 FEGSEM, FEI, Hillsboro, OR, USA).

Crystalline phase analysis of the raw powder and set materials were obtained using an X-ray diffractometer (D8 Advance Powder X-ray Diffractometer, Bruker AXS, Karlsruhe, Germany) with a Ni filter and CuKa radiation $\left(\lambda=1.5425 \AA\right.$ ) at $40 \mathrm{kV}$ and $40 \mathrm{~mA}$ (scan range: $10-80^{\circ}$, scanning rate of $\left.0.02^{\circ} / \mathrm{s}\right)$. Crystalline formations were identified using JCPDS standard data file.

Infra-red spectra were obtained with FT-IR/NIR (Frontier, Perkin Elmer, Waltham, MA, USA) using FT-IR grade potassium bromide ( $\mathrm{KBr}$, Sigma-Aldrich, St. Louis, MO, USA) sample preparation technique. Samples were mixed with $\mathrm{KBr}$ and formed into pellets for analysis (five spectra for each specimen, spectral resolution of $2 \mathrm{~cm}^{-1}, 100$ scans per spectrum). 


\subsection{Setting Time, Hardness, Push-Out Bond Strength, and $p H$}

For setting time $(n=3)$, the materials were inserted into molds immediately after mixing and final setting time assessed every $60 \mathrm{~s}$ with a Gillmore needle (Gilson Company Inc, Delaware County, $\mathrm{OH}$, USA) (453.6 g) according to ASTM C266-13 standard test method [44].

For Knoop hardness (HK), five indentations (100 g, 10 s) were made per specimen using Knoop diamond indenter (FM-100, Futuretech, Kawasaki, Japan) and HK calculated according to Equation (1) where $C_{p}$ is the correction factor related to the shape of the indenter $(0.070279), P$ is the test load $(\mathrm{kgf})$, and $L$ is the length of the longer diagonal $(\mu \mathrm{m})$ :

$$
H K=\frac{P}{C_{p} L^{2}}
$$

For $\mathrm{pH}$ variation, one disk ( $5 \mathrm{~mm}$ diameter $\times 1 \mathrm{~mm}$ thickness) of each group was placed individually in a tube containing $10 \mathrm{~mL}$ of ultrapure water (MilliQ, Millipore, Billerica, MA, USA) and stored at $37^{\circ} \mathrm{C}$. The $\mathrm{pH}$ of the solution was measured (Orion Star ${ }^{\mathrm{TM}} \mathrm{A} 211 \mathrm{pH}$ Benchtop Meter, Thermo Scientific, Waltham, MA, USA) up to $168 \mathrm{~h}$ of incubation $(n=3)$.

For push-out bond strength, the access to the pulp chamber of the premolars were prepared using a round diamond bur (\#1012, KG Sorensen, São Paulo, Brazil) under water irrigation. The working length was determined with a K-file\#10 (Maillefer Dentsply, Ballaigues, Switzerland) and root canals were instrumented up to \#30 under irrigation with saline solution. Finally, the first $8 \mathrm{~mm}$ of the root canal was enlarged to a final diameter of $1.3 \mathrm{~mm}$ (Endo Niti Files Largo Peeso Reamer \#4, Maillefer Dentsply, Ballaigues, Switzerland). Teeth were mounted in epoxy resin and sectioned horizontally (LabCut 1010 Low Speed Diamond Saw, Extec Corp, Enfield, CT, USA). The crown was removed and the root sliced into disks ( $2.0 \pm 0.1 \mathrm{~mm}$ thick). The first cervical disk was rejected and the remaining used for push-out bond strength test $(n=10)$. The disks were filled with the cements and a lentulo spiral (\#25/1, Maillefer Dentsply, Ballaigues, Switzerland) was used to release air bubbles. The teeth were wrapped in wet gauze and specimens stored for seven days in an incubator at $37^{\circ} \mathrm{C}$.

The dentin slices were tested for push-out bond strength $(n=10)$ as previously described by Valandro et al. [45]. The test was performed in a universal testing machine (EMIC DL2000, Paraná, Brazil) at $0.5 \mathrm{~mm} / \mathrm{min}$. The bond strength $\left(\sigma_{P O}\right.$, in $\mathrm{MPa}$ ) was calculated according to Equation (2) where $F$ is the load for specimen rupture (in $\mathrm{N})$ and $A$ is the bonded area $\left(\mathrm{mm}^{2}\right)$ :

$$
\sigma_{P O}=\frac{F}{A}
$$

The bonded area $(A)$ was determined using Equations (2) and (3), where $g$ is the slant height, $R 1$ is the smaller base radius, $R 2$ is the larger base radius and $\mathrm{h}$ is the section height (all in $\mathrm{mm}$ ). $R 1$ and $R 2$ were obtained under optical microscope (Z-TXE, Shangrao, China):

$$
\begin{gathered}
A=\pi g(R 1+R 2) \\
g=\left[h^{2}+(R 2-R 1)^{2}\right]^{1 / 2}
\end{gathered}
$$

\subsection{Dental Pulp Stem Cells Culture, Cell Proliferation, and Bioactivity}

The use of human monoradicular premolars and dental pulp stem cells (DPSC) for research was approved by the Institutional Review Board/NUS (Approval Number: NUS 2094). The DPSC (Allcells, Alameda, CA, USA) between passage 3 and 6 were used to assess the cell proliferation and bioactivity. The characterization for mesenchymal stem cell markers is available elsewhere [19]. Cells were cultured in DMEM (Dulbecco modified Eagle medium (Invitrogen, Carlsbad, CA, USA)) supplemented with $10 \%$ fetal bovine serum (Invitrogen) and 1\% penicillin/streptomycin (Invitrogen) [46]. Cell were passaged (TrypLE Select, Invitrogen, Carlsbad, CA, USA) at $60-70 \%$ of confluence. 
To prepare the extracts, the cements were inserted into molds ( $5 \mathrm{~mm}$ in diameter, $2 \mathrm{~mm}$ in thickness) and allowed to set for $24 \mathrm{~h}$. The discs were immersed individually in $10 \mathrm{~mL}$ of culture medium for seven days. After, the disks were discarded, the eluent filtered (pore size $0.22 \mu \mathrm{m}$ ) and kept at $4{ }^{\circ} \mathrm{C}$ for no longer than two weeks.

For cell viability $(n=3), 10 \times 10^{3}$ cells were seeded in 24 well plates with basal medium and left undisturbed for $24 \mathrm{~h}$. Later, cells were treated with wither basal medium (Control) or with extracts for five days. After three and five days, cells were treated with NucBlue ${ }^{\circledR}$ Live and propidium iodide (ReadyProbes ${ }^{\circledR}$ Cell Viability Imaging Kit, Blue/Red, Life Technologies, Carlsbad, CA, USA) for 15 min and imaged under fluorescence microscope DAPI and RFP filters. For bioactivity $(n=3), 3 \times 10^{4}$ cells were seeded in 24 well plates and treated with the extracts for 14 days. The mineralization was assessed using Alizarin Red S staining (ARS). Briefly, cells fixed in $4 \%$ formaldehyde at room temperature for $30 \mathrm{~min}$. The cells were washed twice with distilled water and $40 \mathrm{mM}$ ARS (pH 4.2) was added to each well. The plates were incubated at room temperature for $30 \mathrm{~min}$, washed four times with distilled water ( 5 min each). Following, $200 \mu \mathrm{L}$ of $10 \%$ acetic acid $(v / v)$ was added to each well and incubated at room temperature for $30 \mathrm{~min}$. Cells were scraped from the plate, transferred to a microcentrifuge tube, and vortexed for $30 \mathrm{~s}$. The solution was kept at $85^{\circ} \mathrm{C}$ for $10 \mathrm{~min}$ and transferred to ice for $5 \mathrm{~min}$. The slurry was then centrifuged and $500 \mu \mathrm{L}$ of the supernatant transferred to a microcentrifuge tube. Finally, $200 \mu \mathrm{L}$ of $10 \%$ ammonium hydroxide $(v / v)$ was added to the solution. Absorbance of aliquots $(100 \mu \mathrm{L})$ of the supernatant were measured using a microplate reader (Infinite M200, Tecan, Frankfurt, Germany) at a wavelength of $405 \mathrm{~nm}$.

Statistical analyses were performed with two-way analysis of variance (ANOVA) followed by post hoc Tukey test ( $\alpha=0.05$, SPSS V.17, IBM, New York, NY, USA).

\section{Conclusions}

The hypothesis was partially rejected as the addition of GNS negatively affected the push-out strength of ECZ. Nonetheless, GNS may be an alternative to improve the hardness and shorten setting time of bioactive cements. The presence of GNS does not interfere negatively in the formation of calcium hydroxide, calcium carbonate, and $\mathrm{pH}$ release profile that are crucial for the bioactivity role and antibacterial properties of the biocements. The decrease in the push-out resistance observed in ECZ may compromise the clinical performance of the material. Hence, despite the improvements observed, the use of GNS cannot be generalized when effective bonding of bioactive cements is of concern.

Supplementary Materials: The following are available online at www.mdpi.com/1996-1944/10/6/606/s1.

Acknowledgments: This research is supported by the National Research Foundation, Prime Minister' Office, Singapore, under its Medium Sized Centre Programme. V.R. was supported by the grants from the Singapore Ministry of Education, Singapore (Academic Research Fund Tier 1, R-221-000-091-112) and National University Health System, Singapore (NUHS Bench-to-Bedside, R-221-000-074-515 and NUHS Open Collaborative Research Grant NUHS O-CRG 25/10/2016); K.-S.M. acknowledges Basic Science Research Program through the National Research Foundation of Korea funded by the Ministry of Education, Science, and Technology (2013-R1A1A4A01006389).

Author Contributions: Nileshkumar Dubey and Sneha S. Rajan were responsible for the following analysis and tests: XRD, SEM, FT-IR, Raman, hardness, setting time, $\mathrm{pH}$, and bioactivity; Yuri Dal Bello performed the push-out assay and fractographic analysis; and Kyung-San Min and Vinicius Rosa designed the study, supervised the experiments, statistical analysis, and wrote the paper.

Conflicts of Interest: Authors declare no conflict of interest. The funding sponsors had no role in the design of the study; in the collection, analyses, or interpretation of data; in the writing of the manuscript, and in the decision to publish the results.

\section{References}

1. Caron, G.; Azerad, J.; Faure, M.O.; Machtou, P.; Boucher, Y. Use of a new retrograde filling material (biodentine) for endodontic surgery: Two case reports. Int. J. Oral Sci. 2014, 6, 250-253. [CrossRef] [PubMed] 
2. Vidal, K.; Martin, G.; Lozano, O.; Salas, M.; Trigueros, J.; Aguilar, G. Apical closure in apexification: A review and case report of apexification treatment of an immature permanent tooth with biodentine. J. Endod. 2016, 42, 730-734. [CrossRef] [PubMed]

3. Michel, A.; Erber, R.; Frese, C.; Gehrig, H.; Saure, D.; Mente, J. In vitro evaluation of different dental materials used for the treatment of extensive cervical root defects using human periodontal cells. Clin. Oral Investig. 2016, 21, 753-761. [CrossRef] [PubMed]

4. Marconyak, L.J.; Kirkpatrick, T.C.; Roberts, H.W.; Roberts, M.D.; Aparicio, A.; Himel, V.T.; Sabey, K.A. A comparison of coronal tooth discoloration elicited by various endodontic reparative materials. J. Endod. 2016, 42, 470-473. [CrossRef] [PubMed]

5. Kang, S.-H.; Shin, Y.-S.; Lee, H.-S.; Kim, S.-O.; Shin, Y.; Jung, I.-Y.; Song, J.S. Color changes of teeth after treatment with various mineral trioxide aggregate-based materials: An ex vivo study. J. Endod. 2015, 41, 737-741. [CrossRef] [PubMed]

6. Hakki, S.S.; Bozkurt, S.B.; Hakki, E.E.; Belli, S. Effects of mineral trioxide aggregate on cell survival, gene expression associated with mineralized tissues, and biomineralization of cementoblasts. J. Endod. 2009, 35, 513-519. [CrossRef] [PubMed]

7. Min, K.S.; Yang, S.H.; Kim, E.C. The combined effect of mineral trioxide aggregate and enamel matrix derivative on odontoblastic differentiation in human dental pulp cells. J. Endod. 2009, 35, 847-851. [CrossRef] [PubMed]

8. Maeda, H.; Nakano, T.; Tomokiyo, A.; Fujii, S.; Wada, N.; Monnouchi, S.; Hori, K.; Akamine, A. Mineral trioxide aggregate induces bone morphogenetic protein-2 expression and calcification in human periodontal ligament cells. J. Endod. 2010, 36, 647-652. [CrossRef] [PubMed]

9. Natu, V.P.; Dubey, N.; Loke, G.C.; Tan, T.S.; Ng, W.H.; Yong, C.W.; Cao, T.; Rosa, V. Bioactivity, physical and chemical properties of mta mixed with propylene glycol. Int. J. Oral Sci. 2015, 23, 405-411. [CrossRef] [PubMed]

10. Kaup, M.; Schafer, E.; Dammaschke, T. An in vitro study of different material properties of biodentine compared to proroot mta. Head Face Med. 2015, 11, 16. [CrossRef] [PubMed]

11. Qing, Y.; Zenan, Z.; Deyu, K.; Rongshen, C. Influence of nano-sio2 addition on properties of hardened cement paste as compared with silica fume. Constr. Build. Mater. 2007, 21, 539-545. [CrossRef]

12. Kong, Y.-M.; Kim, S.; Kim, H.-E.; Lee, I.-S. Reinforcement of hydroxyapatite bioceramic by addition of zro2 coated with al2o3. ChemInform 2010, 31. [CrossRef]

13. Makar, J.; Margeson, J.; Luh, J. Carbon nanotube/cement composites-early results and potential application. In Proceedings of the 3rd International Conference on Construction Materials: Performance, Innovations and Structural Implications, Vancouver, BC, Canada, 22-24 August 2005; pp. 1-10.

14. Musso, S.; Tulliani, J.-M.; Ferro, G.; Tagliaferro, A. Influence of carbon nanotubes structure on the mechanical behavior of cement composites. Compos. Sci. Technol. 2009, 69, 1985-1990. [CrossRef]

15. Vera-Agullo, J.; Chozas-Ligero, V.; Portillo-Rico, D.; García-Casas, M.J.; Gutiérrez-Martínez, A.; Mieres-Royo, J.M.; Grávalos-Moreno, J. Mortar and concrete reinforced with nanomaterials. In Nanotechnology in Construction 3, 1st ed.; Bittnar, Z., Bartos, P.J.M., Němeček, J., Šmilauer, V., Zeman, J., Eds.; Springer: Berlin/Heidelberg, Germany, 2009; pp. 383-388.

16. Morsy, M.S.; Alsayed, S.H.; Aqel, M. Hybrid effect of carbon nanotube and nano-clay on physico-mechanical properties of cement mortar. Constr. Build. Mater. 2011, 25, 145-149. [CrossRef]

17. Dubey, N.; Bentini, R.; Islam, I.; Cao, T.; Castro Neto, A.H.; Rosa, V. Graphene: A versatile carbon-based material for bone tissue engineering. Stem Cells Int. 2015, 2015, 804213. [CrossRef] [PubMed]

18. Xie, H.; Cao, T.; Gomes, J.V.; Castro Neto, A.H.; Rosa, V. Two and three-dimensional graphene substrates to magnify osteogenic differentiation of periodontal ligament stem cells. Carbon 2015, 93, 266-275. [CrossRef]

19. Rosa, V.; Xie, H.; Dubey, N.; Madanagopal, T.T.; Rajan, S.S.; Morin, J.L.; Islam, I.; Castro Neto, A.H. Graphene oxide-based substrate: Physical and surface characterization, cytocompatibility and differentiation potential of dental pulp stem cells. Dent. Mater. 2016, 32, 1019-1025. [CrossRef] [PubMed]

20. Pan, Z.; Duan, W.; Li, D.; Collins, F. Graphene Oxide Reinforced Cement and Concrete. Patent WO2013096990 A1, 4 July 2013.

21. Gong, K.; Pan, Z.; Korayem, A.H.; Qiu, L.; Li, D.; Collins, F.; Wang, C.M.; Duan, W.H. Reinforcing effects of graphene oxide on portland cement paste. J. Mater. Civ. Eng. 2015, 27, A4014010. [CrossRef] 
22. Lv, S.; Ting, S.; Liu, J.; Zhou, Q. Use of graphene oxide nanosheets to regulate the microstructure of hardened cement paste to increase its strength and toughness. CrystEngComm 2014, 16, 8508-8516. [CrossRef]

23. Zhang, L.; Liu, W.; Yue, C.; Zhang, T.; Li, P.; Xing, Z.; Chen, Y. A tough graphene nanosheet/hydroxyapatite composite with improved in vitro biocompatibility. Carbon 2013, 61, 105-115. [CrossRef]

24. Mehrali, M.; Moghaddam, E.; Shirazi, S.F.S.; Baradaran, S.; Mehrali, M.; Latibari, S.T.; Metselaar, H.S.C.; Kadri, N.A.; Zandi, K.; Osman, N.A.A. Mechanical and in vitro biological performance of graphene nanoplatelets reinforced calcium silicate composite. PLoS ONE 2014, 9, e106802. [CrossRef] [PubMed]

25. Thema, F.T.; Moloto, M.J.; Dikio, E.D.; Nyangiwe, N.N.; Kotsedi, L.; Maaza, M.; Khenfouch, M. Synthesis and characterization of graphene thin films by chemical reduction of exfoliated and intercalated graphite oxide. J. Chem. 2013, 2013, 150536. [CrossRef]

26. Marciano, M.A.; Duarte, M.A.; Camilleri, J. Dental discoloration caused by bismuth oxide in mta in the presence of sodium hypochlorite. Clin. Oral Investig. 2015, 19, 2201-2209. [CrossRef] [PubMed]

27. Sarkar, N.K.; Caicedo, R.; Ritwik, P.; Moiseyeva, R.; Kawashima, I. Physicochemical basis of the biologic properties of mineral trioxide aggregate. J. Endod. 2005, 31, 97-100. [CrossRef] [PubMed]

28. Grech, L.; Mallia, B.; Camilleri, J. Characterization of set intermediate restorative material, biodentine, bioaggregate and a prototype calcium silicate cement for use as root-end filling materials. Int. Endod. J. 2013, 46, 632-641. [CrossRef] [PubMed]

29. Von Arx, T.; Hänni, S.; Jensen, S.S. Clinical results with two different methods of root-end preparation and filling in apical surgery: Mineral trioxide aggregate and adhesive resin composite. J. Endod. 2010, 36, 1122-1129. [CrossRef] [PubMed]

30. Chong, B.; Pitt Ford, T.; Hudson, M. A prospective clinical study of mineral trioxide aggregate and irm when used as root-end filling materials in endodontic surgery. Int. Endod. J. 2003, 36, 520-526. [CrossRef] [PubMed]

31. Choi, Y.; Park, S.J.; Lee, S.H.; Hwang, Y.C.; Yu, M.K.; Min, K.S. Biological effects and washout resistance of a newly developed fast-setting pozzolan cement. J. Endod. 2013, 39, 467-472. [CrossRef] [PubMed]

32. Camilleri, J.; Sorrentino, F.; Damidot, D. Investigation of the hydration and bioactivity of radiopacified tricalcium silicate cement, biodentine and mta angelus. Dent. Mater. 2013, 29, 580-593. [CrossRef] [PubMed]

33. Manzur, T.; Yazdani, N.; Emon, M.A.B. Potential of carbon nanotube reinforced cement composites as concrete repair material. J. Nanomater. 2016, 2016, 1421959. [CrossRef]

34. Manzur, T.; Yazdani, N. Optimum mix ratio for carbon nanotubes in cement mortar. KSCE Civ. Eng. 2014, 19, 1405-1412. [CrossRef]

35. Siddique, R.; Mehta, A. Effect of carbon nanotubes on properties of cement mortars. Constr. Build. Mater. 2014, 50, 116-129. [CrossRef]

36. Ahn, E.S.; Gleason, N.J.; Ying, J.Y. The effect of zirconia reinforcing agents on the microstructure and mechanical properties of hydroxyapatite-based nanocomposites. J. Am. Ceram. Soc. 2005, 88, 3374-3379. [CrossRef]

37. Aggarwal, V.; Miglani, S.; Kohli, S.; Singla, M. Comparative evaluation of push-out bond strength of proroot mta, biodentine, and mta plus in furcation perforation repair. J. Conserv. Dent. 2013, 16, 462-465. [CrossRef] [PubMed]

38. Guneser, M.B.; Akbulut, M.B.; Eldeniz, A.U. Effect of various endodontic irrigants on the push-out bond strength of biodentine and conventional root perforation repair materials. J. Endod. 2013, 39, 380-384. [CrossRef] [PubMed]

39. Han, L.; Okiji, T. Uptake of calcium and silicon released from calcium silicate-based endodontic materials into root canal dentine. Int. Endod. J. 2011, 44, 1081-1087. [CrossRef] [PubMed]

40. Nikhil, V.; Madan, M.; Agarwal, C.; Suri, N. Effect of addition of $2 \%$ chlorhexidine or $10 \%$ doxycycline on antimicrobial activity of biodentine. J. Conserv. Dent. 2014, 17, 271-275. [CrossRef] [PubMed]

41. Bhavana, V.; Chaitanya, K.; Dola, B.; Gandi, P.; Patil, J.; Reddy, R. Evaluation of antibacterial and antifungal activity of new calcium-based cement (biodentine) compared to mta and glass ionomer cement. J. Conserv. Dent. 2015, 18, 44-46. [CrossRef] [PubMed]

42. Wataha, J.C. Predicting clinical biological responses to dental materials. Dent. Mater. 2012, $28,23-40$. [CrossRef] [PubMed]

43. Wei, A.; Wang, J.; Long, Q.; Liu, X.; Li, X.; Dong, X.; Huang, W. Synthesis of high-performance graphene nanosheets by thermal reduction of graphene oxide. Mater. Res. Bull. 2011, 46, 2131-2134. [CrossRef] 
44. Standard Test Method for Time of Setting of Hydraulic-Cement Paste by Gillmore Needles; American Association State Highway and Transportation Officials Standard: Washington, DC, USA, 2013; C266-13.

45. Valandro, L.F.; Baldissara, P.; Galhano, G.A.; Melo, R.M.; Mallmann, A.; Scotti, R.; Bottino, M.A. Effect of mechanical cycling on the push-out bond strength of fiber posts adhesively bonded to human root dentin. Oper. Dent. 2007, 32, 579-588. [CrossRef] [PubMed]

46. Rosa, V.; Zhang, Z.; Grande, R.H.; Nor, J.E. Dental pulp tissue engineering in full-length human root canals. J. Dent. Res. 2013, 92, 970-975. [CrossRef] [PubMed]

(c) 2017 by the authors. Licensee MDPI, Basel, Switzerland. This article is an open access article distributed under the terms and conditions of the Creative Commons Attribution (CC BY) license (http://creativecommons.org/licenses/by/4.0/). 